\title{
China and Taiwan edge a shade closer
}

[LONDON] A 'private' visit to Taiwan by China's science and technology minister, chemist Zhu Lilan, appears to have helped pave the way for enhanced scientific and technological collaboration between the two long-standing political rivals.

Zhu attended a seminar and spoke with senior academics and industrialists. But at the end of her 10-day visit, she was reluctant to commit herself to a proposal from Hwang Jenn-Tai, chairman of Taiwan's National Science Council - and as such its top science official - that the two sides should sign an agreement setting out guidelines for future substantial cooperation.

Zhu, a prominent polymer chemist who was appointed to her current post earlier this year (see Nature 392, 528; 1998), is the first communist Chinese cabinet minister to have visited Taipei since nationalist-ruled Taiwan broke away from the People's Republic of China in 1949. Zhu met leading Taiwanese industrialists, including Morris Chang, one of the founders of Taiwan's semiconductor industry, and Y. C. Wang, prominent in the plastics industry. Other visits included Acer Computer, the National Chiao Tung University and the National Tsinghua University.

According to a report from the Central News Agency in Taipei, Zhu said after a seminar held at Taiwan's Industrial Technology Research Institute (ITRI) that technology on mainland China appeared to lag behind that in Taiwan by about 10 years. She added that bilateral exchanges, already growing strongly at an unofficial level, should be strengthened.

At a later press conference, she said she could see no major obstacles to increasing scientific and technological cooperation across the Taiwan Strait, scene of major confrontations in the past - most recently in March 1996, when China held naval exercises in the run-up to Taiwan's presidential election.

Hwang said at the end of Zhu's visit that representatives from the two sides who attended the ITRI seminar reached a consensus on the desirability for greater collaboration. He also expressed optimism that both countries will be able to reach an agreement, perhaps a memorandum of understanding, setting out parameters enabling this to happen.

According to the press agency, Hwang said that he was not disappointed that Zhu had not made a formal response to his proposal, as it was the first time that such a proposal had been put forward, and that, formally, Zhu was visiting in a private capacity. Hwang says that important issues needing to be covered include intellectual property rights, administrative support and the respective roles of industries in the two countries in the global market place. "An agreement addressed to these issues, among others, is crucial," he says.

Zhu, who studied organic chemistry in
Russia in the 1950s and Germany in the 1970s, and remains a professor at Peking University, had said on her arrival in Taiwan that she hoped the science and technology communities from both countries would cooperate with "clear paths and targets", rather than loose verbal promises.

The visit was not without its tensions. At one point Liu Zhentao, director of the CrossStrait Economic and Scientific Exchanges Promotion Centre in Beijing, who headed a 90-member delegation of Chinese industrialists and academics to the ITRI seminar, complained that Taiwan had imposed "too many restrictions" on cross-strait scientific and technological exchanges. In particular, he claimed that China had been forced to cancel plans to display examples of its latest development in biotechnology and in agricultural and defence technologies.

During her visit, Zhu is reported to have said at a dinner with top Taiwanese industrialists that it was impossible to predict whether continuing political differences between the two countries would get in the way of closer collaboration in science and technology. But she expressed confidence that this would not happen. "People who study science are more pragmatic [than politicians]," she said. "This [cooperation] is where our mutual interests lie, and I believe we can definitely push it forward.”

DavidDickson

\section{New Zealand government backtracks on funding promises}

[DUNEDIN] Following a significant cut by the New Zealand government last week in its support for universities, alarm is growing among researchers over the emergence of a radical effort to change the allocation of shrinking funds.

Only two months after a budget that forecast growth, the country is slipping into recession with the coalition government cutting NZ\$316 million (US\$164 million) of public spending to counter the effects of the financial crisis in Asia.

The university sector was the hardest hit, with a cut in the support of student fees of NZ\$50 million. The Treasurer, Winston Peters, claimed that universities could absorb the cut by becoming "more efficient and transparent in administration".

The move breaches a government commitment to 'ring fence' funding for universities by paying a minimum of 75 per cent of the total costs, the remainder to be made up by students' fees. The government share has now been reduced to 72.4 per cent.

Concern over funding is central to a campaign by the Association of University Staff and others to reverse policy decisions

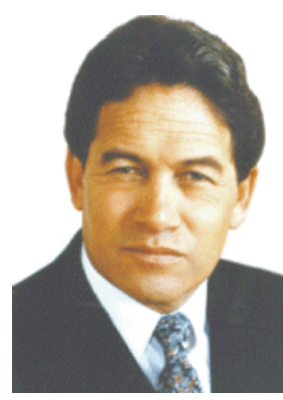

believed to have been drafted for a White Paper on tertiary education. These include plans to split teaching and research functions (see Nature 392, 320 ; 1998).

One point at issue is whether the Peters: unrepentant. government will direct grants towards short-term applications, and whether the funds will be divided according to peer review or a goal-oriented 'business model'.

"The government simply refuses to listen to and respond to our views," says Kelly Duncan, dean of science at Canterbury University. "Any organizational system should reflect realities, and our present system does not. It is a narrow commercial model, so it constrains, misdirects, inhibits and wastes."

The Ministry of Research, Science and Technology is pushing for research to be reprioritized though a 'Foresight' process (see Nature 391, 426; 1998). This has come under severe attack from academics, who are mystified at a language that includes the terms 'Foresight driven sector clusters', 'proxy purchase' and 'provider capture'. But political pragmatists such as Peter Gluckman, dean of the Auckland Medical Schools, say universities cannot risk losing the little funding they already receive, and have no alternative but to "play the game" in the terms of Foresight and the White Paper.

Meanwhile, the country's nine Crown Research Institutes (CRIs) have had to lay off 72 staff owing to a drop in funding, and are objecting to "unfair" competition from universities. The Association of CRIs says the lay-offs are counterbalanced by increases in staff from other sources of support.

After analysing funding trends, which show government targets and real funding moving further apart each year, the 18 council members of the New Zealand Association of Scientists jointly conclude: "Reprioritizing science on a background of a static or falling science budget will only increase the present fears of the science community."

Peter Pockley 